pISSN: 2301-7716; eISSN: 2622-4607

Dewi dkk.

Jurnal Farmasi Udayana, Vol 7, No 2, Tahun 2018, 68-76

\title{
Pemisahan, Isolasi, dan Identifikasi Senyawa Saponin dari Herba Pegagan (Centella asiatica L. Urban)
}

\author{
Dewi, N. L. A. ${ }^{1}$, Adnyani, L. P. S. ${ }^{1}$, Pratama, R. B. R. ${ }^{1}$, Yanti, N. N. D. ${ }^{1}$, Manibuy, J. I. ${ }^{1}$, Warditiani N. K. ${ }^{1}$ \\ ${ }^{1}$ Program Studi Farmasi Fakultas Matematika dan Ilmu Pengetahuan Alam Universitas Udayana, \\ Bukit Jimbaran, Badung, 80361 \\ Email:arysintadewi1@gmail.com
}

\begin{abstract}
ABSTRAK
Pegagan (Centella asiatica L. Urban) mengandung senyawa-senyawa metabolit sekunder seperti triterpenoid, steroid, dan saponin. Herba pegagan dimaserasi dengan etanol:akuades (70:30 v/v) menghasilkan rendemen sebesar 21,346\%. Skrining fitokimia ekstrak menunjukkan hasil positif mengandung saponin. Fraksinasi dilakukan dengan kromatografi kolom lambat dan diperoleh 39 fraksi. KLT subfraksinasi dilakukan pada fraksi no. 4, 5, 8, 10 dengan nilai Rf sebesar 0,45; 0,45; 0,5; dan 0,5375. Dilanjutkan dengan KLT preparatif dengan eluen kloroform: methanol: air (65:25:4 v/v) menunjukkan adanya pita biru yang menunjukkan adanya kandungan saponin. KLT hasil subfraksinasi dilakukan dengan menggunakan eluen kloroform:metanol:akuades (65:25:4 v/v) didapatkan spot berwarna biru dengan nilai Rf sebesar 0,46. KLT Dua Dimensi dilakukan dengan menggunakan dua jenis eluen yaitu 6,9 $\mathrm{mL}$ kloroform, 2,7 mL metanol, 0,4 air $\mathrm{mL}$ dan 5,3 mL kloroform, 2,8 mL asam asetat glasial, 1,1 mL metanol dan 0,7 mL air. Spot hasil KLT dua dimensi berwarna biru dengan Rf 0,5 dan 0,71. Herba pegagan mengandung asiatic acid dan madecassic acid.
\end{abstract}

Kata kunci: Centella asiatica L. Urban, saponin, triterpenoid

\section{ABSTRACT}

Centella asiatica L. Urban contains triterpenoids, steroids, and saponins. C. asiatica L. Urban was macerated with ethanol: water $(70: 30 \mathrm{v} / \mathrm{v})$ yield produced at 21,346\%. Phytochemical screening tests showed that C. asiatica L. Urban extract contains saponins and triterpenoid. Fractionation was carried out by column chromatography and 39 fractions were obtained. TLC subfractionation was carried out only in fraction number 4, 5, 8, 10 there was a blue-purple fluorescence which $\mathrm{Rf}$ value were 0,$45 ; 0,45 ; 0,5$; 0,5375. Preparative TLC was then done carried out (chloroform: methanol: water (65: 25: $4 \mathrm{v} / \mathrm{v} / \mathrm{v})$ ) the presence of a blue band showed saponins contents. The process then continued with TLC (chloroform: methanol: water (65: 25: $4 \mathrm{v} / \mathrm{v} / \mathrm{v})$ ) showed blue spot which its Rf value was 0.46. Lastly, Two-dimensional TLC was carried out using two types of mobile phases which were $6,9 \mathrm{~mL}$ chloroform, 2,7 mL methanol, $0,4 \mathrm{~mL}$ aquadest and 5,3 $\mathrm{mL}$ chloroform, 2,8 $\mathrm{mL}$ glacial acetic acid, 1,1 mL methanol and 0,7 $\mathrm{mL}$ aquadest and gave blue-colored fluorescences spots which its $\mathrm{Rf}$ value were 0,5 and 0,71 respectively. C. asiatica $\mathrm{L}$. Urban contains asiatic acid and madecassic acid.

Keywords: Centella asiatica L. Urban, saponin, triterpenoid 
pISSN: 2301-7716; eISSN: 2622-4607

Dewi dkk.

Jurnal Farmasi Udayana, Vol 7, No 2, Tahun 2018, 68-76

\section{PENDAHULUAN}

Pengembangan obat herbal terus dilakukan melalui pemanfaatan metabolit sekunder yang memiliki potensi besar untuk dikembangkan menjadi obat. Hal ini didukung juga dengan masyarakat yang lebih memilih mengonsumsi obat dari bahan alam karena efek samping yang ditimbulkan lebih rendah dibanding dengan obat sintesis (Sari, 2006). Salah satu tanaman Indonesia yang digunakan sebagai obat adalah pegagan.

Pegagan (Centella asiatica) merupakan tanaman yang sejak dulu digunakan sebagai obat kulit, meningkatkan ketahanan tubuh (panjang umur), membersihkan darah, dan memperbaiki gangguan pencernaan. Efek farmakologis dari pegagan diantaranya sebagai anti infeksi, anti racun, penurun panas, peluruh air seni, anti lepra, anti sipilis, anti pikun, untuk membantu mengatasi stress serta dapat sebagai revitalitas tubuh dan otak otak yang lelah, untuk kesuburan wanita, serta sebagai anti pikun (Kristina dkk., 2009).

Pegagan mempunyai rasa manis dan bersifat sejuk. Kandungan bahan kimia pegagan yaitu asiatikosida, madekosida, brahmosida, tannin, resin, pektin, gula, vitamin B, garam mineral seperti kalium, natrium, magnesium, kalsium, besi, fosfor, minyak atsiri, pektin dan asam amino. Konstituen utama yang terkandung di dalam daun pegagan adalah saponin asiatikosida (Kristina dkk., 2009).

Saponin merupakan kelompok senyawa glikosida dari triterpena dan sterol (Harborne, 1998). Karakteristik kelompok senyawa saponin adalah adanya aglikon steroid ataupun aglikon triterpenoid dan satu atau lebih gugus gula (Üstündağ and Mazza, 2007). Unsur utama dalam saponin triterpen dalam pegagan (Centella asiatica) adalah asiatikosida dan madekassosida. unsur saponin triterpen lain dalam pegagan (Centella asiatica) yaitu asiaticoside, thankuniside, isothankuniside, madecassoside, brabmosede, brahmic acid, madasiatic acid, centelloside (Soenanto, 2009).

Penelitian Rafamantanana et.al. (2009) menggunakan metode untuk mengidentifikasi asiatikosida dengan HPLC-UV namun metode tersebut membutuhkan biaya yang besar dan menggunakan peralatan yang rumit. Maka dari itu dilakukan pemisahan, isolasi serta identifikasi untuk mendapatkan senyawa asiatikosida pada Centella asiatica dengan menggunakan metode maserasi pada tahap ekstraksi, fraksinasi dan subfraksinasi menggunakan metode Kromatografi Kolom Lambat dan Kromatografi Lapis Tipis Preparatif, identifikasi dengan menggunakan metode Kromatografi Lapis Tipis dengan pereaksi Liebermann-Burchard.

\section{BAHAN DAN METODE \\ Bahan dan alat}

Bahan-bahan yang digunakan adalah herba pegagan diperoleh dari daerah Padangsambian Denpasar Barat Bali, methanol (Bratachem ${ }^{\circledR}$ ), ethanol $96 \%$ (Bratachem $\left.^{\circledR}\right)$, n-heksan $\left(\right.$ Bratachem $\left.^{\circledR}\right)$, asam asetat glasial, asam asetat anhidrat, akuades, anisaldehid, $\mathrm{H}_{2} \mathrm{SO}_{4}, \mathrm{HCl} 2 \mathrm{~N}$, plat silika gel $\mathrm{GF}_{254}$ $\left(\mathrm{Merck}^{\circledR}\right)$, bubuk silika gel $60\left(\mathrm{Merck}^{\circledR}\right)$, kloroform $\left(\right.$ Bratachem $\left.^{\circledR}\right)$.

Alat-alat yang digunakan adalah alat-alat gelas, alat penggiling (blender), toples kaca, cawan porselin, timbangan analitik (Adam AFP-360 L), oven, chamber (Camag), pipet kapiler, pinset, cutter, penangas air, termometer, lampu UV $254 \mathrm{~nm}$ dan 366 nm (CAMAG), dan kolom kromatografi.

\section{Metode \\ Preparasi Sampel}

Sebanyak 320 gram simpilisa pegagan yang dibeli dari Supermarket Tiara Dewata Denpasar Bali, dibersihkan dari pengotornya terlebih dahulu kemudian diserbukan dengan menggunakan blender. Ditimbang serbuk daun pegagan sebanyak $300 \mathrm{~g}$.

\section{Ekstraksi}

Dilakukan deffating 250,014 g dengan menggunakan pelarut n-heksan sebanyak $850 \mathrm{ml}$ kemudian dikeringkan hingga tidak tercium bau dari pelarut $\mathrm{n}$-heksan. Selanjutnya dimaserasi pelarut etanol 96\% : air (70:30) sebanyak $1500 \mathrm{~mL}$ selama 
pISSN: 2301-7716; eISSN: 2622-4607

Dewi dkk.

Jurnal Farmasi Udayana, Vol 7, No 2, Tahun 2018, 68-76

tiga hari terlindung dari cahaya dan wadah tertutup dengan sesekali pengadukan. Setelah tiga hari, ampas dan endapan dipisah dari filtratnya. Ampas dan endapan diremaserasi selama dua hari dengan pelarut etanol $96 \%$ : air $1100 \mathrm{~mL}$. Filtrat yang didapat dipekatkan pada suhu $40^{\circ} \mathrm{C}$. Ekstrak kental yang diperoleh ditentukan rendemennya (Biradar and Rachetti, 2013).

\section{Skrining Fitokimia \\ a. Uji untuk saponin}

Ditimbang ekstrak kental sebanyak $15 \mathrm{mg}$ lalu dimasukkan ke dalam tabung reaksi. Ditambahkan akuades sebanyak $10 \mathrm{~mL}$ kemudian tabung reaksi dikocok vertikal selama 10 detik kemudian dibiarkan selama 10 detik. Pembentukan busa setinggi 1-10 cm yang stabil selama tidak kurang dari 10 menit, menunjukkan adanya saponin. Pada penambahan 1 tetes $\mathrm{HCl} 2 \mathrm{~N}$, busa tidak hilang menunjukkan positif saponin.

\section{b. Uji Liebermann-Burchard}

Ditimbang ekstrak kental sebanyak $15 \mathrm{mg}$ lalu dilarutkan dengan kloroform. Ditambahkan 0,5 mL asam asetat anhidrat kemudian ditambahkan $2 \mathrm{~mL}$ asam sulfat pekat melalui dinding. Hasil positif ditunjukkan apabila terbentuk cincin berwarna merah-keunguan pada batas lapisan untuk triterpenoid dan hijau untuk steroid.

\section{Fraksinasi dengan Kromatografi Kolom Lambat}

Dibuat bubur silica gel (fase diam) dengan menimbang $50 \mathrm{~g}$ silica gel dan ditambahkan dengan eluen

(kloroform:metanol:air dengan perbandingan 30:10:1 v/v/v) secukupnya sambil diaduk hingga menjadi bubur. Bubur silica gel yang telah dibuat dimasukkan ke dalam kolom kromatografi yang telah dialasi dengan glass wool melalui dinding kolom agar tidak terbentuk gelembung. Bubur silica gel dimasukkan hingga ketinggian kurang lebih $25 \mathrm{~cm}$ dan selanjutnya didiamkan selama kurang lebih 24 jam untuk memadatkan fase diam. Ekstrak kemudian dielusi dengan menggunakan fase gerak kloroform:metanol:air dengan perbandingan 30:10:1 v/v/v sebanyak $50 \mathrm{ml}$. Fraksi yang diperoleh kemudian disimpan dalam vial dan dibungkus dengan aluminium foil dan plastik ikan. Penentuan fraksi yang mengandung saponin ditentukan dengan menggunakan metode KLT.

\section{KLT Hasil Fraksinasi}

Analisis KLT dilakukan terhadap fraksi hasil fraksinasi dengan kromatografi kolom lambat. Fase diam yang digunakan adalah silika gel $\mathrm{GF}_{254}$ dan fase geraknya adalah kloroform : methanol : air (65:25:4 v/v/v) (Harwoko et al, 2014). Deteksi spot dilakukan dengan UV $366 \mathrm{~nm}$ yang sebelumnya disemprot dengan reagen anisaldehid asam sulfat. Plat Silika Gel $\mathrm{GF}_{254}$ dipotong dengan ukuran $10 \mathrm{x}$ $10 \mathrm{~cm}$. kemudian diaktivasi pada suhu $110^{\circ} \mathrm{C}$ selama 30 menit. Fase gerak dibuat sebanyak $10 \mathrm{~mL}$. Penyiapan pereaksi anisaldehid asam sulfat.

Setiap fraksi ditotolkan pada plat sebanyak 4 $\mu \mathrm{L}$. Plat dielusi sampai jarak $1 \mathrm{~cm}$ dari batas atas plat. Selanjutnya dilakukan penyemprotan dengan menggunakan anisaldehid asam sulfat dan dipanaskan pada suhu $110^{\circ} \mathrm{C}$ selama 10 menit. Anisaldehid asam sulfat akan memberikan warna ungu pada sinar tampak. Glikosida saponin tanpa perlakuan kimia (pereaksi semprot) di bawah sinar $\mathrm{UV}_{254} \mathrm{~nm}$ tidak terjadi pemadaman bercak dan di bawah sinar $\mathrm{UV}_{365} \mathrm{~nm}$ bercak tidak berfluorosensi (Wardhani dan Sulistyani, 2012). Rf Asiatikosida, Madecassoside, Asiatic acid, dan Madecassic acid sebesar 0,$24 ; \quad 0,16 ; 0,7 ;$ dan 0,8 secara berturut-turut (Harwoko et al, 2014).

\section{Kromatografi Lapis Tipis Preparatif}

Subfraksi kromatografi kolom yang telah diuapkan dilarutkan dengan $0,5 \mathrm{~mL}$ metanol sehingga diperoleh ekstrak yang tidak terlalu pekat. Fase Diam yang digunakan plat Silika Gel $\mathrm{GF}_{254}$ dengan ukuran $10 \mathrm{~cm} \times 10 \mathrm{~cm}$ dan fase geraknya adalah kloroform : metanol : air (65:25:4 v/v).

Pembuatan pereaksi Liebermann-Burchard untuk penyemprot, Larutan penyemprot ini harus dibuat baru (Harborne, 1998). 
pISSN: 2301-7716; eISSN: 2622-4607

Dewi dkk.

Jurnal Farmasi Udayana, Vol 7, No 2, Tahun 2018, 68-76

Larutan sampel ditorehkan pada masingmasing plat dalam bentuk pita dengan bantuan pipet. Selanjutnya dieluasi dengan $10 \mathrm{~mL}$ fase gerak yaitu kloroform : metanol : air (65:25:4 v/v) (Harwoko et al, 2014). Plat diamati dibawah sinar $\mathrm{UV}_{254} \mathrm{~nm}$ dan $\mathrm{UV}_{366} \mathrm{~nm}$, kemudian bagian pinggir kiri dan kanan plat KLT preparatif disemprot dengan pereaksi Liebermann-Burchard yang terbuat dari 50 bagian kloroform dicampur dengan 20 bagian asam asetat anhidrat dan 1 bagian asam sulfat pekat. Plat yang telah disemprot dipanaskan pada suhu $85-90^{\circ} \mathrm{C}$ selama 15 menit. Tandai areal yang akan dikerok pada plat yang tidak terkena pereaksi Liebermann-Burchard. Plat KLTP dikerok menggunakan spatula dan hasil kerokan kemudian diekstraksi dengan metanol, kemudian disaring. Rf Asiatikosida, Madecassoside, Asiatic acid, dan Madecassic acid sebesar 0,24; 0,16;0,7; dan 0,8 secara berturut-turut (Harwoko et al, 2014).

\section{KLT Hasil Subfraksinasi}

Dipilih subfraksi yang memberikan warna ungu pada KLTP, ekstrak etanol dan fraksi saponin triterpenoid hasil kromatografi kolom lambat. Masing-masing ekstrak tersebut dilarutkan dengan 0,5 mL metanol sehingga diperoleh ekstrak yang tidak terlalu pekat. Plat Al Silika Gel $\mathrm{GF}_{254}$ dipotong dengan ukuran $2 \mathrm{~cm} \times 10 \mathrm{~cm}$, kemudian diaktivasi pada suhu $110^{\circ} \mathrm{C}$ selama 15 menit.

Fase gerak fase gerak yaitu kloroform : metanol : air (65:25:4 v/v) dibuat sebanyak $10 \mathrm{~mL}$.

Larutan uji ditotolkan pada plat sebanyak 6 $\mu \mathrm{L}$. Plat diletakkan pada chamber yang telah dijenuhkan sebelumnya. Plat dieluasi sampai jarak 1 $\mathrm{cm}$ dari batas atas plat. Plat diangin-anginkan selama 10 menit untuk menguapkan fase gerak pada yang masih tersisa plat. Dilihat di bawah sinar UV 366 dan dicatat nilai Rf. Hasil positif mengandung saponin adalah terdapat spot warna ungu. Subfraksi yang memiliki bercak yang sama digabungkan, dan yang positif mengandung saponin dipilih untuk dilakukan proses pemisahan selanjutnya. Rf Asiatikosida, Madecassoside, Asiatic acid, dan Madecassic acid sebesar 0,24; 0,16; 0,7;dan 0,8 secara berturut-turut (Harwoko et al, 2014).

\section{Identifikasi Isolat dengan KLT Dua Dimensi}

Disiapkan plat KLT silika gel 60 F254 dengan ukuran $10 \times 10 \mathrm{~cm}$, plat dicuci dengan metanol dan di aktivasi dalam oven pada suhu $110^{\circ} \mathrm{C}$ Selama 30 menit.

Fase gerak pertama dibuat sebanyak $10 \mathrm{~mL}$. dipipet sebanyak 6,9 $\mathrm{mL}$ kloroform, 2,7 $\mathrm{mL}$ metanol, dan 0,4 $\mathrm{mL}$ air. Pelarut dimasukkan ke dalam labu ukur $10 \mathrm{~mL}$, kemudian digojog hingga homogen (Harwoko et al., 2014). Fase gerak kedua dibuat sebanyak $10 \mathrm{~mL}$. dipipet sebanyak 5,3 mL kloroform, 2,8 $\mathrm{mL}$ asam asetat glasial, 1,1 $\mathrm{mL}$ metanol, dan 0,7 $\mathrm{mL}$ air. Pelarut dimasukkan ke dalam labu ukur $10 \mathrm{~mL}$, kemudian digojog hingga homogen (James and Dubery, 2011).

Isolat hasil KLTP dilarutkan dengan metanol. Diambil sebanyak $10 \mu \mathrm{L}$ kemudian ditotolkan pada plat KLT. Plat dielusi dengan eluen dengan tingkat kepolaran dan arah yang berbeda. Setelah dielusi plat diangin anginkan selama 10 menit untuk menguapkan fase gerak yang masih tersisa pada plat. Kemudian hasil elusi diamati menggunakan penampak noda sinar ultra violet $254 \mathrm{~nm}$. Hasil pengamatan yang menunjukkan satu bercak atau satu spot tunggal menandakan senyawa isolat yang diperoleh merupakan senyawa kimia tunggal atau murni (Harborne, 1984). Rf Asiatikosida, Madecassoside, Asiatic acid, dan Madecassic acid sebesar 0,$24 ; 0,16 ; 0,7 ;$ dan 0,8 secara berturut-turut untuk fase gerak pertama dan 0,$55 ; 0,45 ; 0,94$; dan 0,97 secara berturut-turut untuk fase gerak kedua (Harwoko et al, 2014; James and Dubery, 2011).

\section{HASIL \\ Preparasi Ekstrak}

Rendemen ekstrak etanol:air herba pegagan (Centella asiatica L. Urban.) yang didapat sebesar $21,346 \%$. 
pISSN: 2301-7716; eISSN: 2622-4607

Dewi dkk.

Jurnal Farmasi Udayana, Vol 7, No 2, Tahun 2018, 68-76

Uji Fitokimia Ekstrak Etanol Herba Pegagan (Centella asiatica L. Urban.)

Ekstrak etanol:air herba pegagan (Centella asiatica L. Urban.) mengandung senyawa golongan triterpenoid dan saponin.

\section{Fraksinasi Ekstrak}

Fraksinasi ekstrak dilakukan dengan kromatografi kolom lambat dengan menggunakan fase gerak kloroform : metanol : akuades (30:10:1) $\mathrm{v} / \mathrm{v} / \mathrm{v}$ dan diperoleh 39 fraksi.

\section{KLT Hasil Fraksinasi}

Tabel 1. Pemilihan 19 fraksi dari 39 fraksi yang diperoleh dan 1 ekstrak pada plat KLT.

\begin{tabular}{cc}
\hline Totolan & Ekstrak/Fraksi \\
\hline 1 & Ekstrak \\
2 & Fraksi 1 \\
3 & Fraksi 4 \\
4 & Fraksi 5 \\
5 & Fraksi 8 \\
6 & Fraksi 10 \\
7 & Fraksi 11 \\
8 & Fraksi 12 \\
9 & Fraksi 13 \\
10 & Fraksi 15 \\
11 & Fraksi 17 \\
12 & Fraksi 23 \\
13 & Fraksi 26 \\
14 & Fraksi 27 \\
15 & Fraksi 29 \\
16 & Fraksi 33 \\
17 & Fraksi 34 \\
18 & Fraksi 36 \\
19 & Fraksi 37 \\
20 & Fraksi 38 \\
& \\
\hline
\end{tabular}

Tabel 2. Nilai Rf masing-masing spot setelah disemprot dengan Pereaksi Semprot AnisaldehidAsam Sulfat dan diamati dibawah UV 254nm.

\begin{tabular}{|c|c|c|}
\hline Fraksi/Spot & $\mathbf{R f}$ & Warna Spot \\
\hline 4 & 0,45 & Pemadaman bercak \\
\hline 5 & 0,45 & Pemadaman bercak \\
\hline 8 & 0,5 & Pemadaman bercak \\
\hline 10 & 0,5375 & Pemadaman bercak \\
\hline \multirow{2}{*}{23} & 0,79375 & Pemadaman bercak \\
\hline & 0,875 & Pemadaman bercak \\
\hline
\end{tabular}
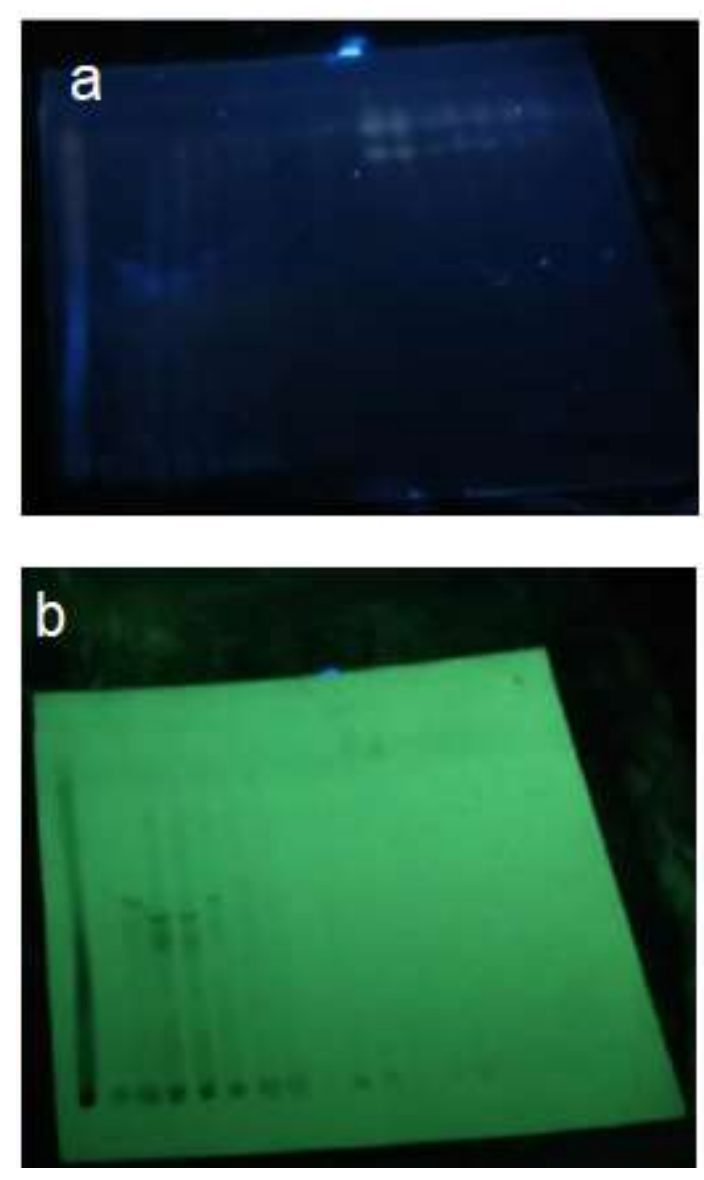

Gambar 1. a. Plat KLT dibawah UV 366nm; b. Plat KLT dibawah UV 254nm setelah disemprot dengan Pereaksi Semprot Anisaldehid-Asam Sulfat. Fluoresensi berwarna biru-ungu menunjukkan adanya kandungan saponin. 
pISSN: 2301-7716; eISSN: 2622-4607

\section{KLT Preparatif}

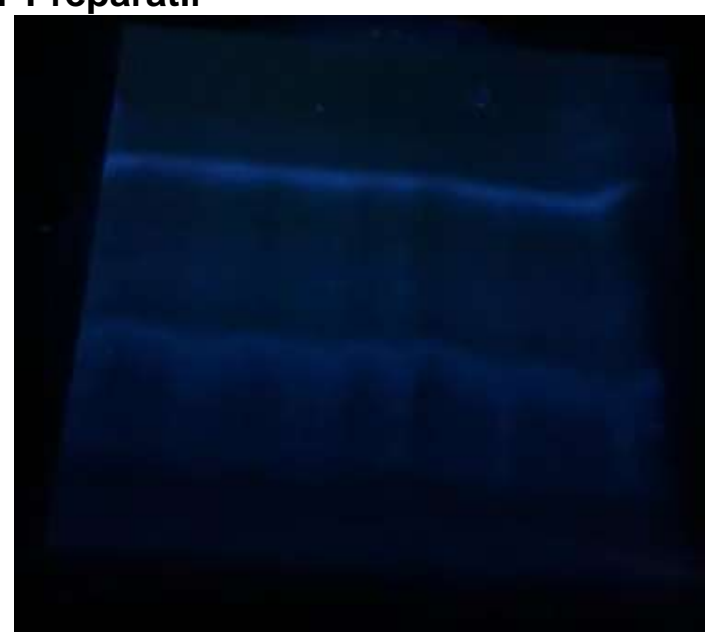

Gambar 2. Hasil KLTP. Pita biru menunjukkan adanya kandungan saponin yang selanjutnya akan dikerok untuk proses identifikasi selanjutnya.

\section{KLT Hasil Subfraksinasi}

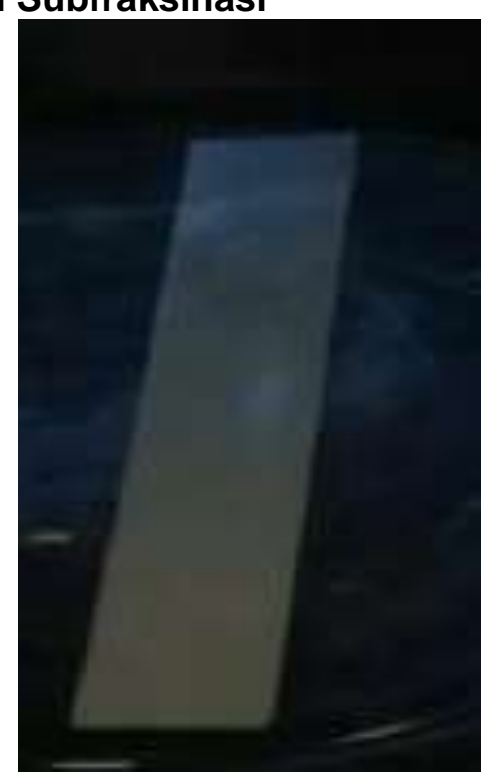

Gambar 3. Plat KLT Hasil Subfraksinasi. Fluoresensi berwarna biru-ungu menunjukkan adanya kandungan saponin.
Tabel 3. Nilai Rf dari spot KLT Hasil Subfraksinasi setelah disemprot Pereaksi Semprot AnisaldehidAsam Sulfat.

\begin{tabular}{ccl}
\hline Fraksi/Spot & Rf & Warna Spot \\
\hline I & 0,46 & Biru \\
\hline
\end{tabular}

\section{KLT Dua Dimensi}

Tabel 4. Nilai Rf dari masing-masing spot dalam dua fase gerak yang berbeda pada KLT Dua Dimensi.

\begin{tabular}{cccl}
\hline Elusi & & Rf & Warna Spot \\
\hline & I & 0,5 & Biru \\
& II & 0,71 & Biru \\
\hline
\end{tabular}

\section{PEMBAHASAN}

Proses ekstraksi diawali dengan proses defatting dengan menggunakan pelarut n-heksan. Defatting bertujuan untuk meng-hilangkan senyawasenyawa pengganggu seperti klorofil dan lipid dari sampel. Sampel diekstraksi dengan metode maserasi. Maserasi merupakan proses ektraksi yang dilakukan dengan pelarut pada suhu kamar dengan sesekali pengadukan di tempat yang terlindung sinar matahari (Sutrisna,2016).

Skrining fitokimia adalah uji konfirmasi awal yang bertujuan untuk membuktikan ada tidaknya senyawa kimia tertentu dalam tumbuhan tersebut yang dapat dikaitkan dengan aktivitas biologinya (Kristanti dkk, 2008). Skrining fitokimia yang dilakukan untuk golongan senyawa saponin adalah Uji Liebermann-Burchard dan Uji Pembentukan Busa. Uji Liebermann-Burchard dilakukan untuk mengetahui apakah terdapat kandungan triterpenoid atau steroid di dalam ekstrak. Kondensasi atau pelepasan $\mathrm{H}_{2} \mathrm{O}$ dan penggabungan dengan karbokation merupakan prinsip dari Uji Liebermann-Burchard. Reaksi ini diawali dengan proses asetilasi gugus hidroksil menggunakan asam asetat anhidrida. Gugus asetil yang merupakan gugus pergi yang baik akan lepas, sehingga terbentuk ikatan rangkap. Selanjutnya terjadi pelepasan gugus hidrogen beserta elektronnya, mengakibatkan ikatan rangkap berpindah. Senyawa 
ini mengalami resonansi yang bertindak sebagai elektrofil atau karbokation. Serangan karbokation menyebabkan adisi elektrofilik, diikuti pelepasan hidrogen. Kemudian gugus hidrogen beserta elektronnya dilepas, akibatnya senyawa mengalami perpanjangan konjugasi yang memperlihatkan munculnya warna merah-ungu (Siadi, 2012).

Uji Pembentukan Busa menunjukkan hasil yang positif apabila terbentuk busa yang stabil setelah pengocokan dan penambahan $\mathrm{HCl} 2 \mathrm{~N}$. Penambahan $\mathrm{HCl} 2 \mathrm{~N}$ bertujuan untuk menambah kepolaran sehingga gugus hidrofil akan berikatan lebih stabil dan buih yang terbentuk menjadi stabil (Simaremare, 2014).

Fraksinasi adalah proses pemisahan untuk memisahkan senyawa - senyawa target ke dalam fraksi yang lebih sederhana. Pemastian keberadaan saponin dalam masing-masing fraksi, dilakukan identifikasi dengan menggunakan KLT. Sebelum penotolan fraksi, plat dicuci terlebih dahulu. Pencucian plat dilakukan dengan menggunakan metanol den selanjutnya diaktivasi dengan menggunakan oven pada suhu $110^{\circ} \mathrm{C}$ selama 30 menit. Aktivasi plat bertujuan untuk menghilangkan pelarut sisa pencucian dan mengaktifkan gugus silanol dan siloksan dari plat.

Selama proses aktivasi plat, dilakukan penjenuhan chamber menggunakan fase gerak. Penjenuhan chamber bertujuan untuk menyamaratakan tekanan uap dari fase gerak yang digunakan sehingga pemisahan dapat berjalan dengan baik (Kusmardiyani dan Nawawi, 1992). Fraksi yang didapatkan dipilih sejumlah 19 fraksi yang dapat mewakili fraksi lainnya dengan melihat kemiripan warna.

Deteksi spot yang dihasilkan dilakukan dengan menggunakan pereaksi semprot anisaldehidasam sulfat. Pereaksi semprot anisaldehid-asam sulfat merupakan pereaksi yang bersifat destruktif karena pereaksi ini memecah senyawa pada plat KLT supaya dapat diamati oleh sinar tampak (Alegantina dkk., 2010). Dari hasil yang diperoleh, fraksi yang diduga mengandung saponin adalah fraksi 1, 4, 5, 8, dan 10 yang menghasilkan spot berwarna biru dengan masing-masing nilai $\mathrm{Rf}$ 0,4875; 0,45; 0,45; 05; dan 0,5375 setelah disemprot dengan anisaldehid-asam sulfat. Saponin akan memberikan warna coklat-ungu setelah disemprot dengan pereaksi anisaldehid-asam sulfat pada UV $366 \mathrm{~nm}$.

Pemurnian dilakukan secara kromatografi lapis tipis (KLT) preparatif menggunakan fase diam silika gel GF254 dan fase gerak kloroform:methanol:air (65:25:4 v/v). Diperoleh 2 pita setelah diamati dibawah sinar UV $254 \mathrm{~nm}$ dan $366 \mathrm{~nm}$ dimana pita pertama berwarna biru gelap dan pita kedua berwarna biru muda terang. Pita yang dihasilkan tidak lurus, melainkan sangat bergelombang. Hal ini mungkin disebabkan oleh pengaruh fase gerak, ukuran sampel, sifat analit dan adanya kontaminan. Pada identifikasi plat KLTP di UV $366 \mathrm{~nm}$ bagian pinggir plat tidak menunjukkan adanya pita yang berwarna. Hal ini kemungkinan disebabkan karena proses pemanasan yang dilakukan tidak optimal. Kedua pita tersebut kemudian dikerok untuk KLT Hasil Subfraksinasi. KLT hasil subfraksinasi dilakukan untuk memastikan dari fraksi KLTP. Hasil yang diperoleh berasal dari pita pertama dimana diperoleh spot berwarna biru dan memiliki nilai Rf 0,46. Adanya spot berwarna biru-ungu mencerminkan adanya kandungan saponin (Harwoko et al., 2014)

KLT dua dimensi merupakan KLT yang menggunakan 2 eluen yang memiliki tingkat kepolaran berbeda. Fase gerak pertama menggunakan campuran 6,9 mL kloroform, 2,7 mL methanol, dan $0,4 \mathrm{~mL}$ air. Fase gerak kedua menggunakan campuran 5,3 mL kloroform, 2,8 mL asam asetat glasial, 1,1 ml metanol dan $0,7 \mathrm{~mL}$ air (Harwoko et al., 2014; James and Dubery, 2011). Sampel yang ditotol merupakan hasil dari KLTP, yang ditotolkan pada plat KLT hingga spot terlihat gelap jika diamati dibawah sinar UV. Spot hasil KLT berwarna biru dengan Rf elusi pertama yaitu 
pISSN: 2301-7716; eISSN: 2622-4607

Dewi dkk.

Jurnal Farmasi Udayana, Vol 7, No 2, Tahun 2018, 68-76

0,5 dimana mendekati dari nilai $\mathrm{Rf}$ madecassic acid karena menurut James and Dubery (2011) madecassic acid memilki nilai Rf sebesar 0,55. Nilai Rf pada elusi kedua diperoleh 0,71 dimana dimana mendekati dari nilai $\mathrm{Rf}$ asiatic acid karena menurut Harwoko et al., (2011) asiatic acid memilki nilai Rf sebesar 0,70 .

\section{KESIMPULAN}

Herba pegagan mengandung madecassic acid dan asiatic acid.

\section{UCAPAN TERIMA KASIH}

Penulis mengucapkan terima kasih kepada semua rekan serta pihak yang telah membantu dan memberi saran pada penelitian ini.

\section{DAFTAR PUSTAKA}

Alegantina, S., A. Isnawati, dan I. Rooslamiati. 2010. Isolasi dan Identifikasi Artemisinin dari Herba Artemisia annua L. Buletin Penelitian Kesehatan. Vol. 38 (3) : 159-168.

Biradar, S.R. dan B.D. Rachetti. 2013. Extraction of Some Secondary Metabolites \& Thin Layer Chromatography from Different Parts of Centella asiatica L. (URB). American Journal of Life Sciences. Vol. 1(6): 243-247.

Harborne, J. B. 1998. Phytochemical Methods. Third Edition. United Kingdom : Chapman \& Hall.

Harwoko, S. Pramono, and A. E. Nugroho. 2014. Triterpenoid-rich Fraction of Centella asiatica Leaves and in vitro Antihypertensive Activity. International Food Research Journal. Vol. 21 (1) : 149-154.

James, J., and I. Dubery. 2011. Identification and Quantification of Triterpenoid Centelloids in Centella asiatica (L.) Urban by Densitometric TLC. Journal of Planar Chromatography. Vol. 24 (1) : 82-87.
Kristanti, A. N., N. S. Aminah., M. Tanjung, dan B. Kurniadi. 2008. Buku Ajar Fitokimia. Surabaya: Jurusan Kimia-Laboratorium Kimia Organik Fakultas Matematika dan Ilmu Pengetahuan Alam Universitas Airlangga.

Kristina, N. N., E. D. Kusumah, P. K. Lailani. 2009. Analisis Fitokimia dan Penampilan Polapita Protein Tanaman Pegagan (Centella asiatica) Hasil Konservasi in vitro. Bul. Littro. Vol. 20 (1) : 11-20.

Kusmardiyani, S. dan A. Nawawi. 1992. Kimia Bahan Alam. Jakarta: Universitas Bidang Ilmu Hayati.

Rafamantanana, M.H., E. Rozet, G.E. Raoelison, K. Cheuk, S.U. Ratsimamanga, Ph. Hubert, J. Quetin-Leclercq. 2009. An Improved HPLCUV Method for The Simultaneous Quantification Of Triterpenic Glycosides And Aglycones In Leaves OfCentella asiatica (L.) Urb (APIACEAE). Journal Of Chromatography B. Vol. 877 (23) : 2396-2402.

Sari, L. O. R. K. 2006. Pemanfaatan Obat Tradisional Dengan Pertimbangan Manfaat dan Keamanannya. Majalah Ilmu Kefarmasian. Vol. 3 (1) : 01-07.

Siadi, K. 2012. Ekstrak Bungkil Biji Jarak Pagar Jatropha curcas sebagai Biopestisida yang Efektif dengan Penambahan Larutan $\mathrm{NaCl}$. Jurnal MIPA. Vol. 35 (1): 77-83.

Simaremare, E. S. 2014. Skrining Fitokimia Ekstrak Etanol Daun Gatal (Laportea decumana (Roxb.) Wedd). PHARMACY. Vol. 11 (1) : 98-107.

Soenanto, H. 2009. 100 Resep Sembubkan Hipertensi,Obesitas Dan Asam Urat. Jakarta:PT Alex Media Kopuntindo.

Sutrisna, E. M. 2016. Herbal Medicine: Suatu Tinjauan Farmakologis. Surakarta: Mahammadiyah University Press. 
pISSN: 2301-7716; eISSN: 2622-4607

Dewi dkk.

Jurnal Farmasi Udayana, Vol 7, No 2, Tahun 2018, 68-76

Üstündağ, Ö. G. and G. Mazza. 2007. Saponins: Properties, Applications and Processing. Critical Reviews in Food Science and Nutrition. Vol. 47 (3) : 231-258.

Daun Binahong (Anredera scandens (L.) Moq.) terhadap Shigella flexneri beserta Profil Kromatografi Lapis Tipis. Jurnal Ilmiah Kefarmasian. Vol. 2 (1) : 1-16.

Wardhani, L. K. dan N. Sulistyani. 2012. Uji Aktivitas Antibakteri Ekstrak Etil Asetat 